\title{
Alcohol Consumption in Southern Sweden after Major Decreases in Danish Spirits Taxes and Increases in Swedish Travellers' Quotas
}

\author{
Nina-Katri J. Gustafsson \\ Centre for Social Research on Alcohol and Drugs, Stockholm University, Stockholm, Sweden
}

\section{Key Words}

Alcohol consumption - Tax decrease $\cdot$ Increased private import quotas

\begin{abstract}
Background: In 2003, Denmark lowered its tax on spirits, and in 2004, Sweden increased its traveller import quotas. Aim: The aim of the study was to determine whether these two changes increased self-reported alcohol consumption in southern Sweden, which is located near Denmark. Method: Data were collected through telephone interviews with the general population between 2003 and 2006. Individuals aged 16-80 years were interviewed. Some lived in southern Sweden, others in the northern region, which was assumed to be unaffected by the policy changes and was thus used as a control site. Analyses were performed for the total population as well as by sex, age, socio-economic group and consumption pattern. Results: The expected results were not found: alcohol consumption in southern Sweden had not changed. The few statistically significant changes found in southern Sweden indicated decreases. In the north, however, consumption seemed to have increased. Conclusion: In addition to the two policy changes mentioned above, other changes seem to have affected alcohol consumption in Sweden. It is possible, however, that the policy changes have affected population groups not reached by the survey, and thus other types of data need to be analysed before drawing any far-reaching conclusions.

Copyright $\odot 2010$ S. Karger AG, Basel
\end{abstract}

\section{Introduction}

On October 1, 2003, Denmark reduced its spirits tax by $45 \%$, resulting in an approximate decrease in price of $25 \%$ [1]. Furthermore, on January 1, 2004, Sweden increased its traveller's allowances as an additional adaptation to the general EU levels of taxes on alcohol that were already in place [2]. These two major changes were expected to increase travellers' imports to Sweden, particularly in the southern parts located close to Denmark and Germany. The aim of the present paper is to examine to what extent this change in availability of cheap alcohol led to an increase in alcohol consumption in southern Sweden and whether various segments of the population were affected differently. Studying drinking in the whole population, and not only among travellers, is warranted by the fact that imported alcohol is likely to be consumed by non-travellers as well. For instance, it is well established that imported alcohol is illegally sold to minors [3], and it is also likely to be consumed by friends and family members of the person doing the importing. In addition, drinking in the whole population is an important outcome variable as it has a significant bearing on public health. Based on the assumption that northern Sweden was hardly affected by these changes at all, this area was included in the analyses as control. This assumption is corroborated by earlier studies showing that previous increases in traveller's allowances in Sweden (i.e. in 1995) have stimulated alcohol consumption, especially among

\section{KARGER}

(C) 2010 S. Karger AG, Basel

Fax +41613061234 E-Mail karger@karger.ch www.karger.com www.karger.com/ear
B. Soc. Sc. Nina-Katri J. Gustafsson

Centre for Social Research on Alcohol and Drugs (SoRAD)

Sveaplan, Stockholm University

SE-106 91 Stockholm (Sweden)

Tel. +468674 7047, Fax +468674 7686, E-Mail nina-katri.gustafsson@ sorad.su.se 
Table 1. Total average consumption according to the way of obtaining alcoholic beverages [7, pp. 29-31]

\begin{tabular}{|c|c|c|c|c|c|c|c|c|}
\hline & \multicolumn{4}{|c|}{ Scania/Skåne } & \multicolumn{4}{|c|}{ Norrland } \\
\hline & 2003 & 2004 & 2005 & 2006 & 2003 & 2004 & 2005 & 2006 \\
\hline Registered consumption & 4.7 & 4.5 & 4.4 & 4.6 & 7.0 & 6.9 & 6.8 & 7.0 \\
\hline Traveller import & 4.9 & 5.2 & 5.4 & 3.6 & 0.9 & 1.0 & 0.7 & 0.8 \\
\hline Smuggling & 1.3 & 0.8 & 1.2 & 0.8 & 0.2 & 0.4 & 0.7 & 0.5 \\
\hline Total consumption & 11.4 & 10.9 & 11.1 & 9.0 & 8.4 & 8.9 & 8.5 & 8.9 \\
\hline
\end{tabular}

people living close to the Danish and German borders, i.e. people living in southern Sweden $[4,5]$. Even before the above-mentioned changes were put into effect, people in the south $(76 \%)$ travelled abroad more often than did people in the north $(50 \%)$ [unpublished results in the Nordic tax study]. In fact, although the number of people reporting bringing back alcohol during the last trip did not differ much between the sites $(60 \% / 55 \%)$ [unpublished results in the Nordic tax study], the volume of imported alcohol consumed differed. Individuals living in the southernmost part of Sweden (Scania) bought close to half (43\%) of their alcohol (volume) abroad, whereas the corresponding proportion in northern Sweden was only $11 \%[6,7]$ (also see table 1). Sixty-two percent of imported alcohol in Sweden was purchased in Denmark or Germany [6].

The main reason for expecting alcohol consumption to increase is that the combined effect of the tax reduction and increased allowances implies a significant price reduction in southern Sweden in particular. This hypothesis is grounded in the fundamental law of economics, which links the price of a product to the demand for that product, and consequently the idea that a reduction in the price of alcohol (through a decrease in taxes) would be expected to increase alcohol consumption $[8,9]$. It is also worth noting that few other changes occurred in Sweden between 2003 and 2006 with respect to alcohol prices and availability, which increases the likelihood that any conceivable changes are related to these two policy changes. The only more significant change was that beer prices decreased by about $10 \%$ during the study period.

In the Nordic countries, the magnitude of the effect of changes in alcohol availability and price has been found to vary as a function of population subgroups, e.g. demographic groups and drinking categories [9], and this possibility will therefore be explored here. An additional and more obvious idea is that men would be more affected than women, as they consume more alcohol in general and more spirits in particular [10]. With respect to other population subgroups, however, such as age, income and educational level groups, it is more difficult to identify any clear hypothesis. Heavier drinkers are expected to be more affected than other groups, as they drink large amounts of alcohol and especially spirits, which was the beverage to which the tax change applied. Some of the people in this group may have less financial means to travel abroad to buy larger amounts at the same time, but there are also opportunities to buy alcohol from friends/neighbours and organized smugglers. Additionally, previous research [11] has suggested that policy changes often have the greatest impact on the group of heavy drinkers.

The degree to which Swedes are affected by a price change in Denmark or another foreign country has not been previously studied in any direct manner, but one study found that the Swedish currency devaluation in 1992 was linked to an increase in recorded sales, presumably reflecting a decrease in the amount of alcohol bought from abroad [5]. Another study showed that the influence of lower foreign prices decreases with increasing distance from the border [12]. Still, as already mentioned, even before the changes, people closest to the border (southern Sweden, which is part of the study site) were obtaining about half of their alcohol from a foreign country [6]. One Swiss study looked at the impact of a tax reduction on foreign spirits sold in Switzerland as well as the impact of liberalization of spirits imports [13]. Alcohol consumption was found to have increased at a 3-month follow-up, mainly among younger persons [14]. The Swiss study had many similarities with the current study, although in the present case the tax change did not actually occur in Sweden. Thus, the present study adds a new dimension by investigating how a country's alcohol consumption is affected by the combination of a tax decrease in a neighbouring country and increasing travellers' allowances in the country studied. 
The present study is part of the 'Nordic Tax Study' [1], the general aim of which is to look at how increased alcohol availability, due to tax reductions and increased traveller's quotas, affects alcohol consumption and alcohol-related problems in different Nordic areas. The main approach involves repeated general population surveys in which both cross-sectional and longitudinal samples are collected for four waves 2003-2006. Northern Sweden was used as a quasi-experimental control area for the other three areas (Southern Sweden, Denmark and Finland). As this site used to have lower rates of shopping abroad for alcohol [2] and is also farther away from the intervention site, we could expect it to be less affected by the decrease in spirits taxes and by the possibility to bring in larger amounts of alcohol from abroad. In the first follow-up for the period 2003-2004, the expected increase in consumption was not found in southern Sweden, nor was it found in Finland and Denmark [15]. Even more unexpected was that an increase was instead found in northern Sweden, an area assumed to be unaffected by the policy changes and therefore included as control. For Finland, analyses including 2005 as well mainly confirmed the first results showing no increase in consumption [16], as did the recent analyses of Danish data by Grittner et al. [17] (showing that consumption decreased in 2006).

The present study offers the first longer follow-up of the development in southern Sweden, covering the period 2003-2006. As the first findings in Mäkelä et al. [15] were quite unexpected, it was important to discover whether the same pattern also appears when two additional years are added to the follow-up period. Could it be that a rise in alcohol consumption emerges more slowly as a result of increased stockpiling in southern Sweden in the short run, which would eventually lead to an increase in actual drinking? It is further important to clarify whether the increase in consumption found in northern Sweden (the control area) was of a temporary nature or whether the same result is revealed also after two additional years. Thus, the present paper focuses on changes in alcohol consumption between 2003 and 2006 as compared to those between 2003 and 2004. The changes will be studied in different consumption groups as well as by sex, age, education and income. Although the present focus is on the successive cross-sectional samples, some analyses were carried out on panel data as well, to determine whether these results point in the same direction.

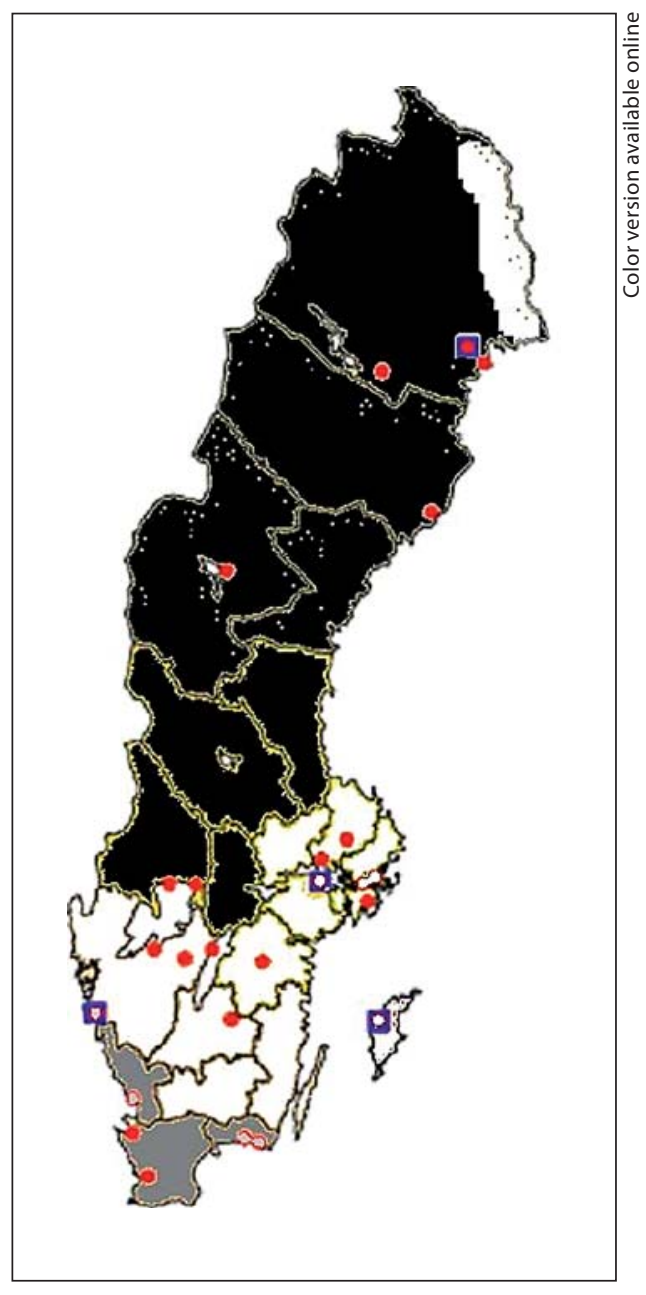

Fig. 1. Overview of the sites in the study: grey area = southern Sweden intervention site; black area $=$ northern Sweden control site; white area $=$ not included in the study.

\section{Data and Methods}

A telephone survey was carried out by the national survey institute Synovate Sweden AB (previously Temo) with the help of Computer Aided Telephone Interviews (CATI). A sample of the adult Swedish population was selected before the Danish tax change during the third quarter (August-October) of 2003 using random digit dialling until 1,500 respondents were reached each month. For the purposes of the present study, respondents living in the southern and northern regions of Sweden were included. The southern area is defined by its closeness to Denmark by bridge or ferry, and the northern area, which served as control, is assumed to be unaffected by the policy changes. Because additional similar changes in taxes and travellers' allowances were taking place in Finland within the same time frame, five districts $100 \mathrm{~km}$ or less from the Finnish border in regions farther to the north were dropped from the analysis (fig. 1). For more background details concerning the study, see Room [18]. 
The southern sample in 2003 included 1,425 individuals 16-80 years of age; 1,336 were interviewed from the northern region the same year. The response rate was estimated at $50.5 \%$ in the southern and $48.4 \%$ in the northern region. Cross-sectional samples were collected during the same period in 2004, 2005 and 2006 as well with responding response rates of $46.9,48.5$ and $37.9 \%$ in the south and $44.2,45.6$ and $33.4 \%$ in the north. Additionally, the individuals in the 2003 sample were re-interviewed in 2004, 2005 and 2006, using the same method, resulting in a panel sample that was interviewed on each occasion, once for each of the 4 years. The sample consisted of 697 individuals in the southern region and 670 individuals in the northern region. The re-interview completion rate (all 3 re-interviews) for the southern region was $79.1 \%$ of the 2003 respondent sample, and the corresponding rate for the northern region was $77.7 \%$. The results from the panel will also be discussed here, but not shown in the tables.

The volume of drinking was measured using a beverage-specific quantity-frequency scale referring to the past 12 months. Trends in drinking of different classes of alcoholic beverages were tested for six classes of beverages. Five of these are sold for offpremises consumption only in government monopoly stores (Systembolaget), including 'alcopops', spirits-based premixed drinks or cider. The sixth class, class II beer, which is composed of beer with either 2.8 or $3.5 \%$ alcohol by volume, is sold in supermarkets and neighbourhood groceries.

Analyses of the total volume were performed for the total sample as well as for different subgroups, using the SAS computer software, version 9.1. For the purpose of the present paper, four age groups were established: 16-29, 30-49, 50-64 and 65-80 years. In the panel sample, age was defined by the respondent's age at the 2003 interview. Total consumption of alcohol as well as beverage-specific consumption are reported in litres of pure $(100 \%)$ alcohol per year. Binge drinkers, here defined as those who report drinking, on the same occasion, alcohol equivalent to at least one bottle of wine, 5 drums $(25 \mathrm{cl})$ of spirits, 4 cans of strong beer or strong cider or 6 cans of medium-strength beer at least monthly, and the highest $10 \%$ of consumers were additionally identified. The effects of the Danish tax decrease and the increase in quotas were tested in two ways. (1) Year-by-year trends in southern Sweden, the 'intervention site', were studied: how much did consumption increase between the years 2003 2004? Was the increase maintained in 2005? In 2006? The focus will be on the comparison with later years. For cross-sectional samples, means were analysed using t tests, and for panel samples, paired t tests were used. Panel data served as control for the cross-sectional analysis. (2) Because the changes in southern Sweden could reflect general shifts in Swedish society, comparisons were also made with trends in northern Sweden, the 'control site', which should not have been affected by the intervention. Whether the difference in change between years in the crosssectional samples was significantly different in the southern site compared to the northern site was tested using regression analysis with a dummy variable for survey year. Differences in change (between years) between the two regions in the panel data were analysed using generalized estimation equation methods [19]. In these tests, the trends in northern Sweden per se should be irrelevant, but because the results are so surprising, they are taken into account in the discussion. All analyses reported for the cross-sectional samples were weighted by sex and age group using a year- and site-specific weight. The panel samples were not weighted as the main interest here was in looking at how the same individuals changed, rather than in making the group representative of the population. For more details on the present methods, see Mäkelä et al. [1].

\section{Results}

The results do not support the hypothesis that alcohol consumption in the southern area increased more or decreased less than it did in the north; in fact there was no statistically significant evidence of an overall increase at all in the southern area, although there were several nonsignificant trends. In the Results section, non-significant trends $(p>0.05)$ will not be taken into consideration or discussed, but for interested readers, these results are presented in the tables.

\section{Year-to-Year Changes in Average Alcohol}

Consumption in Southern Sweden

Gender and Age. Table 2 describes mean (the average) alcohol consumption in total, for 2003 and changes between this year and years 2004-2006, as well as by sex and age. No significant increase in consumption was found in 2004, 2005 or 2006 in the southern region. Analyses of medians gave the same result. Nor was any significant change among men found in the south; by age, no significant increases were observed in any age group or by any year. Women, by any age group, did not change their consumption significantly in 2004 or 2006, although there seems to have been a temporarily significant decrease among women in 2005 mainly due to a decrease in the youngest age group. Thus, the expected increase among men in the southern parts of Sweden was not found in the data. It also did not seem to be the case that any of the age groups were affected more by these changes than others were.

Different Socio-Economic Groups. Changes in consumption for various education and income levels are shown in table 3 . There were no significant changes in consumption in any of the educational level groups, other than a significant decrease among women with at least upper secondary school in 2005. This change did not remain in 2006 (or was not significant). For income groups, a significant decrease was observed among women with low income in 2005, but not in 2006. In 2006, only men with the highest income were found to have decreased their consumption significantly. The analyses of socioeconomic groups using two measures gave somewhat disparate results, but in general both measures pointed in 
Table 2. Average alcohol consumption for the complete samples and by sex and age (consumption in litres of pure alcohol per year)

\begin{tabular}{|c|c|c|c|c|c|c|c|c|}
\hline & \multicolumn{4}{|c|}{ Southern Sweden } & \multicolumn{4}{|c|}{ Northern Sweden } \\
\hline & $\begin{array}{l}2003 \\
\text { mean } \pm S D\end{array}$ & $\begin{array}{l}\text { change } \\
03-04, \%\end{array}$ & $\begin{array}{l}\text { change } \\
03-05, \%\end{array}$ & $\begin{array}{l}\text { change } \\
03-06, \%\end{array}$ & $\begin{array}{l}2003 \\
\text { mean } \pm S D\end{array}$ & $\begin{array}{l}\text { change } \\
03-04, \%\end{array}$ & $\begin{array}{l}\text { change } \\
03-05, \%\end{array}$ & $\begin{array}{l}\text { change } \\
03-06, \%\end{array}$ \\
\hline & $\mathrm{n}=1,425$ & & & & $\mathrm{n}=1,336$ & & & \\
\hline Complete sample & $4.54 \pm 8.17$ & 2 & $-11^{\#}$ & -5 & $2.99 \pm 5.04$ & 8 & 7 & $17^{* *}$ \\
\hline Men & $6.39 \pm 10.73$ & -5 & -7 & $-10^{\# \#}$ & $4.07 \pm 6.15$ & 11 & 15 & $31^{* * *}$ \\
\hline Women & $2.82 \pm 4.63$ & 12 & $-22^{* *, \#}$ & 5 & $1.81 \pm 3.40$ & 8 & -1 & -4 \\
\hline Men & $\mathrm{n}=634$ & & & & $\mathrm{n}=639$ & & & \\
\hline $16-29$ years & $9.42 \pm 14.37$ & $-28^{\# \#}$ & $-30^{*}$ & -16 & $5.19 \pm 7.74$ & 22 & 5 & 30 \\
\hline $30-49$ years & $5.63 \pm 10.41$ & 8 & -2 & $-24^{\# \#}$ & $4.07 \pm 5.48$ & 11 & -1 & $42^{* *}$ \\
\hline 50-64 years & $5.28 \pm 7.52$ & 13 & 12 & 24 & $4.09 \pm 6.66$ & -9 & 28 & 15 \\
\hline $65-80$ years & $4.71 \pm 6.03$ & 12 & 21 & -3 & $2.39 \pm 3.56$ & 26 & $58^{*}$ & 51 \\
\hline Women & $\mathrm{n}=791$ & & & & $\mathrm{n}=697$ & & & \\
\hline $16-29$ years & $3.78 \pm 6.39$ & -2 & $-38^{* *, \#}$ & 3 & $2.20 \pm 2.93$ & 31 & 18 & 16 \\
\hline $30-49$ years & $2.95 \pm 4.63$ & 23 & -20 & 6 & $2.05 \pm 4.06$ & -7 & -17 & -18 \\
\hline $50-64$ years & $2.54 \pm 3.08$ & 15 & -21 & -17 & $1.74 \pm 3.51$ & 12 & -1 & -15 \\
\hline $65-80$ years & $1.41 \pm 2.10$ & 33 & 37 & 83 & $1.09 \pm 1.94$ & -5 & 4 & 22 \\
\hline
\end{tabular}

Significance of difference from 2003: ${ }^{*} \mathrm{p}<0.10,{ }^{* *} \mathrm{p}<0.05,{ }^{* * *} \mathrm{p}<0.01$. Significance of interyear change compared to interyear change in the control region: ${ }^{\#} \mathrm{p}<0.10,{ }^{\# \#} \mathrm{p}<0.05$.

The table shows the mean volume (and the standard deviation) in litres of pure alcohol per year for 2003 as well as changes in the means between 2003-2004, 2003-2005 and 2003-2006.

the same direction and no significant increase in consumption was observed in any socio-economic group after the changes.

Heavy Drinkers. Looking more closely at those who binge drink at least monthly (table 4), there was no significant increase in average volume of drinking in the southern site, nor were there any significant changes by sex. Among the younger persons (16-49 years), however, consumption decreased significantly in 2005 , but the change was not found to be significant in 2006. To see whether there would be a stable result for the group of heavy drinkers when another measure of heavy consumption was used, analyses were also carried out for the group of the $10 \%$ who consumed the most. No significant increase was found in the total sample of those living in the southern site, nor were there any significant changes among men or women. During 2005, younger heavy drinkers in the south were again shown to have decreased their consumption significantly, and here as well, the change did not remain significant in 2006. Consequently, these two measures of heavy consumption gave the same picture: No changes in heavy consumption were found for the southern sample other than a temporary decrease among the youngest individuals in 2005.
Changes in Beverage Preferences. Changes in consumption of class II beer, strong beer, table wine, fortified wine, alcopops or cider and spirits are shown in table 5. Given the reduction in Danish tax on spirits, it was assumed that spirits consumption in particular would increase in the southern region. No significant change in spirits consumption or in any other beverage type could be found in the south, however, except for a temporarily significant decrease in fortified wine and alcopops (commonly consumed by younger individuals) between 2003 and 2005. Although the major policy change entailed a decrease in the price of spirits, an increase in spirits consumption could not be confirmed.

\section{Comparing Changes in Southern Sweden with Those in Northern Sweden}

Part of the aim was also to compare the southern site with the control site in the north, as the hypothesis was that even if a significant increase in consumption in the south were not observed, there would at least be a smaller decrease in this site compared to the northern region. The expected result was not obtained. In fact, where a significant difference in the change in mean consumption was found between the two regions, it was due to a 
Table 3. Average alcohol consumption by sex and social class (education, income)

\begin{tabular}{|c|c|c|c|c|c|c|c|c|}
\hline & \multicolumn{4}{|c|}{ Southern Sweden } & \multicolumn{4}{|c|}{ Northern Sweden } \\
\hline & $\begin{array}{l}2003 \\
\text { mean } \pm \mathrm{SD}\end{array}$ & $\begin{array}{l}\text { change } \\
03-04, \%\end{array}$ & $\begin{array}{l}\text { change } \\
03-05, \%\end{array}$ & $\begin{array}{l}\text { change } \\
03-06, \%\end{array}$ & $\begin{array}{l}2003 \\
\text { mean } \pm \mathrm{SD}\end{array}$ & $\begin{array}{l}\text { change } \\
03-04, \%\end{array}$ & $\begin{array}{l}\text { change } \\
03-05, \%\end{array}$ & $\begin{array}{l}\text { change } \\
03-06, \%\end{array}$ \\
\hline Men & $\mathrm{n}=634$ & & & & $\mathrm{n}=639$ & & & \\
\hline \multicolumn{9}{|l|}{ Education } \\
\hline High, tertiary & $5.54 \pm 5.81$ & 23 & 20 & -3 & $4.31 \pm 6.31$ & -11 & 30 & -6 \\
\hline Middle, upper secondary & $6.40 \pm 9.59$ & $-7^{\#}$ & -5 & -3 & $4.28 \pm 5.97$ & 28 & 10 & $29^{*}$ \\
\hline Low, less than upper secondary & $7.60 \pm 17.28$ & -28 & $-42^{*, \#}$ & $-28^{\#}$ & $3.50 \pm 6.47$ & 7 & 10 & $65^{*}$ \\
\hline \multicolumn{9}{|l|}{ Income } \\
\hline High & $8.10 \pm 14.79$ & -13 & -12 & $-43^{* *, \# \#}$ & $5.19 \pm 7.86$ & -6 & -8 & 19 \\
\hline Medium & $5.44 \pm 7.91$ & 6 & 10 & $-9^{\# \#}$ & $3.77 \pm 4.92$ & 8 & $27^{*}$ & $32^{* *}$ \\
\hline Low & $7.67 \pm 13.37$ & $-19^{\#}$ & $-33^{*, \#}$ & 7 & $3.95 \pm 6.80$ & 48 & 16 & 47 \\
\hline Women & $\mathrm{n}=791$ & & & & $\mathrm{n}=697$ & & & \\
\hline \multicolumn{9}{|l|}{ Education } \\
\hline High, tertiary & $3.15 \pm 4.33$ & 34 & -2 & 38 & $2.34 \pm 3.89$ & 3 & -5 & -12 \\
\hline Middle, upper secondary & $2.71 \pm 4.60$ & 15 & $-34^{* *, \#}$ & -6 & $1.77 \pm 3.41$ & 22 & 3 & 1 \\
\hline Low, less than upper secondary & $2.50 \pm 5.24$ & -25 & -36 & -31 & $1.34 \pm 2.62$ & -4 & -10 & -2 \\
\hline \multicolumn{9}{|l|}{ Income } \\
\hline High & $4.12 \pm 5.58$ & 45 & -18 & -36 & $2.89 \pm 3.32$ & 2 & 21 & -20 \\
\hline Medium & $2.78 \pm 3.86$ & 24 & -11 & $42^{*}$ & $1.92 \pm 3.39$ & 7 & 7 & 4 \\
\hline Low & $2.82 \pm 5.33$ & -6 & $-33^{* *}$ & -24 & $1.55 \pm 2.30$ & 21 & -12 & 1 \\
\hline
\end{tabular}

Significance of difference from 2003: ${ }^{*} \mathrm{p}<0.10,{ }^{* *} \mathrm{p}<0.05$. Significance of interyear change compared to interyear change in the control region: ${ }^{\#} \mathrm{p}<0.10,{ }^{\# \#} \mathrm{p}<0.05$.

The table shows the mean volume (and the standard deviation) in litres of pure alcohol per year for 2003 as well as changes in the means between 2003-2004, 2003-2005 and 2003-2006.

decrease in the southern region and an increase in the northern region.

Gender and Age. As seen in table 2, men in the north were found to have changed their consumption significantly differently from those in the south between 2003 and 2006. Between these years, also the group of men aged $30-49$ years changed differently in the two sites. For these two differences in change, the results by region were only significant in the northern site. Additionally, the development for men aged 16-29 years was significantly different in the regions between 2003 and 2004, but this difference did not remain significant the following years or have any ground in significant results by region.

Different Socio-Economic Groups. Only one group, men with a medium income, was shown to have changed differently in the two sites by socio-economic status (table 3). Also for this difference, the significant change occurred in the north and not the south.

Heavy Drinkers. Table 4 shows that older heavy consumers (highest 10\%) changed differently in southern and northern Sweden in 2004. Even if there were no significant changes within the sites, this difference was actually due to a larger increase in the south than in the north; and although the difference in change did not remain the following years, the increase was larger in the south in (2005 and) 2006 as well. Using this measure, a significant difference between the sites was also observed among the younger persons (aged 16-49 years) in 2005 and in 2006. The difference in change among the younger individuals $(\mathrm{p}<0.01)$ was observed when using the binge-drinking measure as well. Additionally, the total sample of binge drinkers in the northern sample changed their consumption significantly differently from those in the southern sample in 2006. There was no significant difference in change observed between the sites by sex.

Changes in Beverage Preferences. The people in the northern area of Sweden were not found to have changed differently than those in the south in terms of which beverage they preferred (table 5). 
Table 4. Average alcohol consumption in the total groups of monthly binge drinkers and the highest $10 \%$ consumers, and by sex and age

\begin{tabular}{|c|c|c|c|c|c|c|c|c|}
\hline & \multicolumn{4}{|c|}{ Southern Sweden } & \multicolumn{4}{|c|}{ Northern Sweden } \\
\hline & $\begin{array}{l}2003 \\
\text { mean } \pm S D\end{array}$ & $\begin{array}{l}\text { change } \\
03-04, \%\end{array}$ & $\begin{array}{l}\text { change } \\
03-05, \%\end{array}$ & $\begin{array}{l}\text { change } \\
03-06, \%\end{array}$ & $\begin{array}{l}2003 \\
\text { mean } \pm S D\end{array}$ & $\begin{array}{l}\text { change } \\
03-04, \%\end{array}$ & $\begin{array}{l}\text { change } \\
03-05, \%\end{array}$ & $\begin{array}{l}\text { change } \\
03-06, \%\end{array}$ \\
\hline Binge drinkers & $\mathrm{n}=374$ & & & & $\mathrm{n}=289$ & & & \\
\hline Complete sample & $10.26 \pm 12.87$ & 1 & $-18^{*}$ & $-14^{\#}$ & $7.31 \pm 7.16$ & 24 & -1 & $21^{*}$ \\
\hline Men & $11.63 \pm 14.83$ & $-10^{\#}$ & -18 & $-8^{\#}$ & $8.06 \pm 8.06$ & 20 & 0 & $36^{* * *}$ \\
\hline Women & $7.03 \pm 7.03$ & 40 & $-24^{*}$ & $-24^{*}$ & $5.10 \pm 3.70$ & 47 & -9 & $-22^{*}$ \\
\hline Younger (16-49) & $10.13 \pm 13.28$ & 3 & $-24^{* *, \#}$ & $-17^{\# \#}$ & $6.93 \pm 6.32$ & 33 & 0 & $30 * * *$ \\
\hline Older $(50-80)$ & $11.03 \pm 10.13$ & -13 & 2 & -10 & $8.50 \pm 9.57$ & 0 & -4 & -3 \\
\hline Heavy consumers & $\mathrm{n}=139$ & & & & $\mathrm{n}=132$ & & & \\
\hline Complete sample & $21.70 \pm 16.76$ & 9 & $-17^{*, \#}$ & 3 & $14.27 \pm 9.03$ & 14 & 7 & $28^{* *}$ \\
\hline Men & $21.68 \pm 17.78$ & -4 & -17 & $-2^{\#}$ & $14.32 \pm 8.79$ & 7 & 6 & $39 * * *$ \\
\hline Women & $21.78 \pm 11.23$ & 55 & -24 & 20 & $14.04 \pm 10.15$ & 50 & 11 & -21 \\
\hline Younger (16-49) & $24.60 \pm 18.47$ & -12 & $-29^{* *, \# \#}$ & $-14^{\# \#}$ & $14.57 \pm 8.78$ & 17 & 3 & $25^{*}$ \\
\hline Older $(50-80)$ & $15.87 \pm 9.12$ & $73^{\# \#}$ & 16 & $57^{*}$ & $13.76 \pm 9.59$ & 5 & 15 & 33 \\
\hline
\end{tabular}

Significance of difference from 2003: ${ }^{*} \mathrm{p}<0.10,{ }^{* *} \mathrm{p}<0.05,{ }^{* * *} \mathrm{p}<0.01$. Significance of interyear change compared to interyear change in the control region: ${ }^{\#} \mathrm{p}<0.10,{ }^{\# \#} \mathrm{p}<0.05$.

The table shows the mean volume (and the standard deviation) in litres of pure alcohol per year for 2003 as well as changes in the means between 2003-2004, 2003-2005 and 2003-2006. Heavy consumers = highest 10\%.

\section{Trends in Northern Sweden}

As mentioned earlier, the focus was not on what happened in northern Sweden, but as there were some interesting findings in this area, they will be discussed as well.

Gender and Age. As found in table 2, alcohol consumption in the north increased compared to 2003, and this change was found to be significant in 2006. This was also true for men $(\mathrm{p}<0.01)$ and especially in the group aged 30-49 years. Among women and the other age groups, no changes were found to be significant.

Different Socio-Economic Groups. As seen in table 3, socio-economic status did not play a great role in northern Sweden. Although there were tendencies towards significant changes among men, it was only the group of men with medium income that changed (increased) significantly between 2003 and 2006. Among the women, no such change was found.

Heavy Drinkers. Increases in consumption among heavy drinkers (table 4) were found among male binge drinkers $(\mathrm{p}<0.01)$ as well as among men in the group of high consumers (highest 10\%) ( $p<0.01$ ) between 2003 and 2006. For binge drinking, a significant increase $(\mathrm{p}<$ 0.01 ) between 2003 and 2006 was additionally found among those younger than 50 years, and although nonsignificant, the results pointed in the same direction also when using the other measurement for heavy drinking, e.g. high consumers. For the total population in the north, a significant increase in consumption was observed in 2006 among the highest $10 \%$ consumers, and while not significant, results for the total group of binge drinkers also pointed in the same direction.

Changes in Beverage Preferences. Beverages preferences (table 5) did not change in 2004 in the northern site, but in 2005 a significant decrease was noted for fortified wine. This change, however, did not remain in 2006. For this last year, a significant increase was noted in the consumption of (strong) beer.

\section{Did Panel Data Support the Results from the \\ Cross-Sectional Data?}

For most groups, mean consumption in the panel (interviewed at all four measurement points) in southern Sweden (table not shown) was not shown to be significant, but pointed in the same direction as the cross-sectional samples. That is, overall consumption seemed to have decreased in the southern area between 2003 and 2006, as did consumption among men, while in the northern area consumption seemed to have increased for the total sample and for men. For women, there was no congruence between the longitudinal data and the cross- 
Table 5. Average alcohol consumption for specific beverages

\begin{tabular}{|c|c|c|c|c|c|c|c|c|}
\hline & \multicolumn{4}{|c|}{ Southern Sweden } & \multicolumn{4}{|c|}{ Northern Sweden } \\
\hline & $\begin{array}{l}2003 \\
\text { mean } \pm S D\end{array}$ & $\begin{array}{l}\text { change } \\
03-04, \%\end{array}$ & $\begin{array}{l}\text { change } \\
03-05, \%\end{array}$ & $\begin{array}{l}\text { change } \\
03-06, \%\end{array}$ & $\begin{array}{l}2003 \\
\text { mean } \pm S D\end{array}$ & $\begin{array}{l}\text { change } \\
03-04, \%\end{array}$ & $\begin{array}{l}\text { change } \\
03-05, \%\end{array}$ & $\begin{array}{l}\text { change } \\
03-06, \%\end{array}$ \\
\hline & $\mathrm{n}=1,425$ & & & & $\mathrm{n}=1,336$ & & & \\
\hline Beer class II & $0.44 \pm 1.85$ & 14 & -7 & 27 & $0.44 \pm 1.42$ & -11 & -14 & -2 \\
\hline Beer & $1.30 \pm 3.31$ & 6 & -1 & 11 & $0.97 \pm 2.81$ & 24 & 4 & $37^{* *}$ \\
\hline Table wine & $1.68 \pm 7.44$ & 6 & $-20^{\#}$ & $-26^{*}$ & $0.82 \pm 1.87$ & 18 & 45 & 0 \\
\hline Fortified wine & $0.14 \pm 0.80$ & -50 & $-50^{* *}$ & 107 & $0.12 \pm 0.96$ & -25 & $-58^{* *}$ & -8 \\
\hline Alcopops & $0.20 \pm 0.94$ & -10 & $-35^{* *}$ & 25 & $0.13 \pm 0.62$ & 0 & -23 & $62^{*}$ \\
\hline Spirits & $0.97 \pm 3.28$ & -6 & -11 & -13 & $0.55 \pm 1.54$ & -2 & 18 & 25 \\
\hline
\end{tabular}

Significance of difference from 2003: ${ }^{*} \mathrm{p}<0.10,{ }^{* *} \mathrm{p}<0.05$. Significance of interyear change compared to interyear change in the control region: ${ }^{\#} \mathrm{p}<0.10$.

The table shows the mean volume (and the standard deviation) in litres of pure alcohol per year for 2003 as well as changes in the means between 2003-2004, 2003-2005 and 2003-2006.

sectional samples. The results for the panel data concerning changes by age and education were in accordance with the cross-sectional data for most groups, and strengthened our confidence in the finding that there was an actual decrease in consumption in the southern region and an increase in the northern region in most population groups.

\section{Discussion}

The main aim of the present paper was to study whether the reduction in Danish spirits taxes in October 2003 and the increase in Swedish travellers' quotas in January 2004 gave rise to an increase in alcohol consumption in southern Sweden - a region in which almost half of all alcohol consumed is purchased abroad. More specifically, the study aimed at replicating the first short-term evaluation of these changes by adding two additional years to the follow-up period. Such a study was warranted, particularly because some unexpected changes were noted in Sweden between 2003 and 2004. For instance, there was no increase in consumption in southern Sweden during 2004, and consumption tended to rise in the northern region, which was assumed to be less affected by the reforms and was therefore initially regarded as a control. In the present paper too, the northern parts of Sweden served as a control area, and results from the southern region were compared to those from the northern region. Analyses were performed on cross-sectional as well as longitudinal data although the present paper focused on the cross-sectional samples.

The new study did not change the results from the earlier study. When significant results were revealed, they were always in the opposite direction from that predicted initially. As in the short-term evaluation, no signs of increasing alcohol consumption could be found in southern Sweden in the longer follow-up. Instead, the small non-significant overall increase found in 2004 had turned into a decrease in 2006. The decline applied essentially to men. Further, the results revealed that the increase in consumption in northern Sweden in 2004 was not temporary, but continued during subsequent years. On the whole, this pattern was also valid for various population segments as well as for different drinking categories.

We have no definite explanations to offer for this unexpected outcome, but will present some ideas here. One possible reason for the development in southern Sweden is that the changes only affected those who actually went abroad and not the whole population (these changes did not affect the resale of the privately imported alcohol), as was expected. More detailed analyses (not shown here), however, did not reveal a significant increase either in the consumption of spirits or in the total amount of alcohol consumed by those who had been abroad. Still, looking at travellers who brought in alcohol, there was actually a positive trend in total consumption and spirits consumption although it did not reach statistical significance. One interpretation is, thus, that there might have been an in- 
crease in consumption in this specific group, but that it was too small to be of significance for the whole population.

The fact that an effect of these changes demanded a trip to another country increases the importance of economic factors. Petrol prices increased drastically $(+19 \%)$ between 2003 and 2006 [20], which might lead one to expect that trips made by car would decrease. During this period, however, the number of vehicles crossing the Öresund bridge from the Swedish side actually increased by $53 \%$ [21]. The total number of persons crossing the bridge (by car, bus or train) increased by 38\% [21]. Air passengers [22] also increased (+3\%) while ferry passengers decreased (-8\%) [23]. Although these statistics do not only include Swedes, they give the picture that travels to Denmark from Sweden seem to have increased during the study period. Additionally, the disposable income among Swedes has also increased heavily $(+10 \%)$ [24], which is the reason why economic changes might not be able to explain the absence of increases in alcohol consumption during this period.

Another circumstance that might be of importance is that total alcohol consumption in Sweden had increased a great deal for several years prior to 2004, with some indications that the most pronounced increase occurred in the southern regions [6]. This large increase in consumption since the mid-1990s, which does not apply to northern Sweden, may have implied that consumption had reached a point of saturation in the southern regions. The phenomenon of saturation (and explanations underlying this in relation to the Nordic Tax Study and other studies on change and stasis in consumption) has been discussed more closely by Room et al. [25].

It may also be noted that fluctuations in alcohol consumption, like the decreases suggested to occur in southern Sweden, are not a new phenomenon. 'Long waves of alcohol consumption', a phrase originally coined by Mäkelä et al. [26], refers to regular patterns of rise and fall found in industrial countries that cannot be explained by factors normally considered to cause consumption changes. If there is a change in long-term trends, it seems likely that it would start from areas that show heavy consumption and that have perhaps 'led' the increasing trend. At present, however, the importance of 'saturation' and 'long waves' for the recent development in southern Sweden warrants more detailed analysis before it is possible to draw any definite conclusions. Nevertheless, the data at hand suggest that the increase in consumption we find in northern Sweden and the decrease we find in the southern region may both be part of a convergence of drinking patterns in Sweden. It is, however, also worth noting that the increase in consumption in the northern region was largely driven by increasing consumption of strong beer and that this is reasonable, as beer prices decreased by $10 \%$ during the study period. This might explain some of the increase we found in the northern site, as the retail monopoly has a large share of the consumption there. However, this makes it even more puzzling that we did not find an increase in consumption in the southern region.

Naturally, the present study has several limitations. One is that the size of the samples was fairly small, increasing the risk of not revealing changes that actually did occur and of obtaining findings 'by chance', especially for subgroups of the population. On the other hand, it is not likely that this would explain the diverging regional trends, which are actually in accordance with other indicators of alcohol consumption in Sweden, indicators not based on self-reported consumption. Estimates of smuggling and travellers' imports have increased or remained stable in northern Sweden between 2003 and 2006 whereas there was a significant decline in southern Sweden [7] (table 1). Furthermore, when recorded consumption is taken into consideration, estimated total consumption has increased in northern Sweden between 2003 and 2006 whereas it has declined in southern Sweden.

Another possible limitation is that southern and northern Sweden initially had different levels of consumption, which may call into question the adequacy of using northern Sweden as a control area. Still, this cannot shed light on the fact that no increase was observed in southern Sweden, and we cannot overlook the fact that the possibilities to take advantage of the new conditions brought about by policy changes were very different between the two regions.

It is also well established that heavy drinkers are overrepresented among survey non-respondents [27] (and additionally they dropped out of the panel to a greater degree). Consequently, if these groups did increase their drinking, such an increase is not likely to have been fully captured in this type of general population survey. It will therefore be important to complement the present findings with analyses of other indicators of increased consumption, such as alcohol-related mortality and hospitalization, in order to understand what is happening in Sweden. 


\section{Acknowledgements}

This analysis is part of the study 'Effects of major changes in alcohol availability', conducted collaboratively by researchers at the Centre for Social Research on Alcohol and Drugs, Stockholm University, the Faculty of Health Sciences, University of Southern Denmark, Esbjerg, and the Alcohol and Drug Research Group of the National Research and Development Centre for Welfare and Health (STAKES), Helsinki. The author is very thankful for the discussions within the group, especially to Pia Mäkelä and Robin
Room for their valuable advice on earlier versions. The author would also like to thank Anders Leifman for valuable statistical advice and Mats Ramstedt for helpful comments.

The study has received support from the Joint Committee for Nordic Research Councils for the Humanities and the Social Sciences (NOS-HS, project 20071), the US National Institute on Alcohol Abuse and Alcoholism (R01 AA014879), and the national funds in Denmark, Finland and Sweden. For Sweden, partial funding for the 2003 data collection came from Systembolaget AB (the Swedish Alcohol Retailing Monopoly).

\section{References}

1 Mäkelä P, Bloomfield K, Gustafsson N-K, Room R: Effects of major changes in alcohol availability: study design, data collection procedures and measurement. SoRAD Research Report, No 46. Stockholm, Stockholm University, Centre for Social Alcohol and Drug Research, 2007.

2 Leifman H, Gustafsson N-K: En skål för det nya millenniet. En studie av svenska folkets alkoholkonsumtion i början av 2000-talet (A toast for the new millennium: a study of the alcohol consumption in the Swedish population in the beginning of the 21st Century). SoRAD Research Report, No 11. Stockholm, Stockholm University, Centre for Social Alcohol and Drug Research, 2003.

3 Svensson J, Hradilova Selin K: Alkoholsmuggling i Sverige 2002-2006 (Smuggling of alcohol in Sweden 2002-2006). SoRAD Research Report, No 49. Stockholm, Stockholm University, Centre for Social Alcohol and Drug Research, 2005.

4 Norström T: Cross-border trading of alcohol in southern Sweden - substitution or addition?; in Holder HD (ed): Sweden and the European Union: Changes in National Alcohol Policy and Their Consequences. Stockholm, Almqvist \& Wiksell International, 2000, pp 221-238.

5 Trolldal B: Cross-border shopping of alcoholic beverages in the southern part of Sweden after the EU-membership in 1995 and the devaluation of the Swedish currency in 1992; in Holder HD (ed): Sweden and the European Union: Changes in National Alcohol Policy and Their Consequences. Stockholm, Almqvist \& Wiksell International, 2000, pp 97-119.

6 Trolldal B, Boman U, Gustafsson N-K: Alkoholkonsumtionen och dess olika delmängder 2004 (The alcohol consumption and its different subsets). SoRAD Research Report, No 28. Stockholm, Stockholm University, Centre for Social Alcohol and Drug Research, 2005.

7 Boman U, Hradilova Selin K, Ramstedt M, Svensson J: Alkoholkonsumtionen i Sverige fram till år 2006 (Alcohol consumption in Sweden until 2006). SoRAD Research Report, No 48. Stockholm, Stockholm University, Centre for Social Alcohol and Drug Research, 2007.
-8 Chaloupka FJ, Grossman M, Saffer H: The effects of price on alcohol consumption and alcohol-related problems. Alcohol Res Health 2002;26:22-34.

9 Mäkelä P, Rossow I, Tryggvesson K: Who drinks more and less when policies change? The evidence from 50 years of Nordic studies; in Room R (ed): The Effects of Nordic Alcohol Policies: What Happens to Drinking and Harm When Alcohol Controls Change? NAD Publication No. 42. Helsinki, Nordic Council for Alcohol and Drug Research, 2002, pp 17-70.

10 Leifman H: Vilka dricker mer alkohol Sverige? En studie av konsumtionstrender bland män och kvinnor i olika åldersgrupper 1990-2002 (Who drinks more alcohol in Sweden? A study of consumption trends among men and women and various age groups 1990-2002). Appendix; in Leifman H, Gustafsson N-K (eds): SoRAD Research Report, No 11. Stockholm, Stockholm University, Centre for Social Alcohol and Drug Research, 2003.

11 Room R, Romelsjö A, Mäkelä P: Conclusion. Impact of alcohol policy: the Nordic experience; in Room R (ed): The Effects of Nordic Alcohol Policies: What Happens to Drinking and Harm When Alcohol Controls Change? NAD Publication No. 42. Helsinki, Nordic Council for Alcohol and Drug Research, 2002, pp 17-70.

12 Asplund M, Friberg R, Wilander F: Demand and Distance: Evidence on Cross-Border Shopping. SSE/EFI Working Paper Series in Economics and Finance, Report No 587. Stockholm, Stockholm School of Economics, 2005.

13 Heeb J-L, Gmel G, Zurbrügg C, Kuo M, Rehm J: Changes in alcohol consumption following a reduction in the price of spirits: a natural experiment in Switzerland. Addiction 2003;98:1433-1446.

14 Kuo M, Heeb J-L, Gmel G, Rehm J: Does price matter? The effect of decreased price on spirits consumption in Switzerland. Alcohol Clin Exp Res 2003;27:720-725.

15 Mäkelä P, Bloomfield K, Gustafsson N-K, Huhtanen P, Room R: Changes in volume of drinking after changes in alcohol taxes and travellers' allowances: results from a panel study. Addiction 2007;103:181-191.
16 Mustonen H, Mäkelä P, Huhtanen P: People are buying and importing more alcohol than ever before. Where is it all going? Drugs Educ Prev Policy 2007; 14:513-527.

17 Grittner U, Gustafsson N-K, Bloomfield K: Changes in alcohol consumption in Denmark after the tax reduction on spirits. Eur Addict Res 2009;15:216-223.

18 Room R: Att lappa ihop en politikstudie (Patching together a policy study). NAT 2004;21:345-349.

19 Fitzmaurice GM, Laird NM, Ware JH: Applied Longitudinal Analysis. Hoboken, Wiley, 2004.

20 Svenska petroleum Institutet (SPI) (Swedish Petrol Institute): Petrol prices in Sweden 1981-2008. http://www.spi.se/statistik.asp? art=56 (retrieved 2009-09-11).

21 Skatteministeriet (The Danish Ministry of Taxation). Kapitel 2: Påvirkninger af grænsehandlen fra 2006 til 2007 (Chapter 2: The impact of border trade from 2006 until 2007). http://www.skm.dk/publikationer/ udgivelser/statusovergraensehandel2007/ 5731 (retrieved September 12, 2009).

22 SIKA: Luftfart (Air). http://www.sika-institute.se/Templates/Page_49.aspx (retrieved September 11, 2009).

23 SIKA: Sjöfart [Ship traffic]. http://www.sikainstitute.se/Templates/Page_59.aspx (retrieved September 11, 2009).

24 Disponibel inkomst per konsumtionsenhet för individer (Disposable income per consumption unit per person) http://www.scb. se/Pages/TableAndChart_28883.aspx (retrieved September 11, 2009).

25 Room R, Österberg E, Ramstedt M, Rehm J: Explaining change and stasis in alcohol consumption. Addict Res Theory DOI: 10.1080/ 16066350802626966.

26 Mäkelä K, Room R, Single E, Sulkunen P, Walsh D, et al: Alcohol consumption, production, and trade; in Alcohol, Society and the State: 1A Comparative Study of Alcohol Control. Toronto, Addiction Research Foundation, 1981, pp 7-8.

27 Kühlhorn E, Hibell B, Larsson S, Ramstedt M, Zetterberg HL: Alkoholkonsumtionen i Sverige under 1990-talet (Alcohol consumption in Sweden during the 1990s). Stockholm, Oberoende Alkohol Samarbetet (OAS), Socialdepartementet, 1999. 